PressAcademia Procedia

\title{
TESTING FOR HERDING BEHAVIOR IN STOCK MARKET: BIST 30 INDEX EXAMPLE
}

\author{
DOI: 10.17261/Pressacademia.2020.1362 \\ PAP- V.12-2020(26)-p.91
}

Tugba Nur Topaloglu

Sirnak University, Department of Health Management, Sirnak, Turkey.

nurtugba.91@gmail.com, ORCID: 0000-0002-0974-4896

\section{To cite this document}

Topaloglu, T.N., (2020). Testing for herding behavior in stock market: BIST30 index example. PressAcademia Procedia (PAP), V.11, p.91.

Permemant link to this document: http://doi.org/10.17261/Pressacademia.2020.1362

Copyright: Published by PressAcademia and limited licenced re-use rights only.

\section{ABSTRACT}

Purpose- In the study, using weekly data of 19 companies that are constantly traded in the BIST 30 index, in the period 06.05.201227.09.2020, Christie and Huang's (1995) and Chang et al. (2000) approach was aimed to test herd behavior.

Methodology- In the study test of herd behavior, Christie and Huang (1995) and Chang et al. (2000) approaches were used. First, as dependent variable cross-sectional absolute deviations for the price series are calculated. Independent variables are assigned as dummy variables for the lower/upper extreme values of $1 \%$ and $5 \%$ of the market return. Afterwards, estimations were made with Least Squares and Quantile Regression methods.

Findings- As a result of the estimation made with Least Squares and Quantile Regression methods, While the coefficient of $\beta_{1}$ for the $1 \%$ return slice is statistically significant and the positive, coefficient $\beta_{2}$ as statistically significant and negative, for the $5 \%$ return slice, both times the coefficient are statistically significant and positive. The coefficients should be statistically significant and negative in order to pay to show the presence of herd behavior. As a result of the findings, it can be mentioned that 19 firms that are constantly traded in the BIST 30 index have herd behavior for a $1 \%$ return slice in the $2012-2020$ period.

Conclusion- As a result of the analyzes made to determine herd behavior in the period of 06.05.2012-27.09.2020 by using weekly data of 19 companies that are continuously traded in the BIST 30 index, the existence of herd behavior in the relevant period observed. Accordingly, it can be said that investors investing in the BIST 30 index trust the information of other investors when their stock prices tend to fall and invest with this information.

Keywords: Behavioral Finance, Herd Behavior, Equity Market, Quantile Regression, Least Squares

JEL Codes: G41, C22,D53

\section{PAY PIYASALARINDA SÜRÜ DAVRANIŞININ TEST EDILMESi: BIST 30 ENDEKSI ÖRNEĞi}

\section{ÖZET}

Amaç- Çalışmada BIST 30 endeksinde devamlı olarak işlem gören 19 firmanın haftalık verileri kullanılarak 06.05.2012-27.09.2020 döneminde Christie ve Huang'ın (1995) ve Chang vd. (2000) yaklaşımı ile sürü davranışının test edilmesi amaçlanmıştır.

Metodoloji- Çalışmada sürü davranışını tespit edebilmek Christie ve Huang'ın (1995) ve Chang vd. (2000) yaklaşımları kullanılmıştır. İlk olarak bağımlı değişken olan fiyat serilerine ilişkin yatay kesit mutlak sapmaları hesaplanmıştır. Bağımsız değişkenler, piyasa getirisinin \%1 ve \%5' lik getiri dilimlerinin alt/üst uç değerleri için kukla değişken olarak atanmıştır. Ardından En Küçük Kareler ve Kantil Regresyon yöntemleri ile tahminleme yapılmıştır.

Bulgular- En Küçük Kareler ve Kantil Regresyon yöntemleri ile yapılan tahminleme sonucunda, \%1 getiri dilimi için $\beta_{1}$ katsayısı istatistiksel olarak anlamlı ve pozitif $\beta_{2}$ katsayısı ise istatistiksel olarak anlamlı ve negatif olarak tespit edilirken, \%5 getiri dilimi için her iki kat sayıda istatistiksel olarak anlamlı ve pozitif olarak tespit edilmiştir. Sürü davranışının varlığından söz ödebilmek için katsayıların istatistiksel olarak anlamlı ve negatif olması gerekmektedir. Bulgular sonucunda BisT 30 endeksinde devamlı olarak işlem gören 19 firmanın $2012-2020$ döneminde \%1'lik getiri dilimi için sürü davranışının varlığından söz edilebilmektedir.

Sonuç- BIST 30 endeksinde devamlı olarak işlem gören 19 firmanın haftalık verileri kullanılarak 06.05.2012-27.09.2020 döneminde sürü davranışının tespit edilebilmesi için yapılan analizler sonucunda, ilgili dönemde \%1'lik getiri dilimi için tamamen gözlemlenmemesine rağmen getirinin piyasanın üst uç değerlerinde bulunduğu dönemde sürü davranışının varlığından söz edilebilmektedir. Bu doğrultuda BisT 30 endeksine yatırım yapan yatırımcıların pay senedi fiyatları düşme eğiliminde olduğu zaman diğer yatırımcıların bilgilerine güvendikleri ve bu bilgiler ile yatırım yaptıkları söylenebilir.

Anahtar Kelimeler: Davranışsal Finans, Sürü Davranışı, Pay Piyasası, Kantil Regresyon, En Küçük Kareler JEL Kodları: G41,C22,D53

\section{REFERENCES}

Chang, E. C., Cheng, J. W., Khorona, A. (2000). An examination of herd behavior in equity markets: An international perspective. Journal of Banking and Finance, 24(10): 1651-1779.

Christie, W.,Huang, R. D. (1995). Following the pied piper: Do individual returns herd around the market? Financial Analysts Journal, 51(4): 31-37. 